\title{
Peran Komisaris Independen dalam Mewujudkan Good Corporate Governance di Perusahaan Publik
}

\author{
Badriyah Rifai \\ Fakultas Hukum Universitas Hasanuddin Sulawesi Selatan \\ mbad2045@yahoo.co.id
}

\begin{abstract}
The existence of independent commissioner is aimed to set up climate which is more objective, and independent as well as to keep fairness and to give balance berween the interest of majority share holders and the proctection of interest of minority share holders, even the interes of other stakeholders. Independent commissioner is very needed bt the exiting companies in Indonesia, particulary for public companies. With the existence of independent commissioner, all the concern parties have great benefit, especially through the establishment of condition which is suitable with the principle of Good Corporate Governance, where independent commissioner can give opinion with the higher level of independence and accountablity
\end{abstract}

Keywords: : independent comissioner, good corporate governance

\section{Pendahuluan}

Corporate Governance menjadi hal yang sangat penting, dengan adanya krisis moneter pada 1998, yang melanda negara di Asia Tenggara, terutama Indonesia. Ditambah lagi adanya krisis ekonomi global yang terjadi akhirakhir ini, yang melanda hampir di seluruh dunia termasuk negara adidaya seperti Amerika.

Keterpurukan sektor bisnis lebih dirasakan akibat kurang efektifnya pengelolaan perusahaan oleh manajemen yang didukung lemahnya mekanisme pengawasan yang dilakukan dewan komisaris.

Good Corporate Governance (GCG) merupakan proses yang sangat panjang, yang membutuhkan komitmen, kerjasama dan dukungan dari 
berbagai unsur dalam masyarakat. Meskipun saat ini telah ada undangundang perseroan terbatas yang baru yaitu UU NO.40 tahun 2007, tetapi masih banyak peraturan yang terkait untuk terciptanya GCG, sedang yang belum dimandemen misalnya undang undang Pasar Modal.

Tercetusnya semangat reformasi di Indonesia memberikan suatu dorongan yang cukup besar bagi perbaikan tatanan usaha dan pengelolaan perusahaan yang profesional, sehat dan bertanggung jawab. Krisis yang berkepanjangan yang melanda Indonesia, tuntutan persaingan global, dan kebutuhan akan modal turut memberikan andil yang cukup besar bagi reformasi GCG di Indonesia. Reformasi GCG yang telah dimulai sejak tahun 2000 bukanlah suatu pekerjaan mudah, mengingat hal tersebut merupakan proses panjang dan membutuhkan komitmen kerjasama serta dukungan dari berbagai elemen masyarakat. ${ }^{1}$ Secara nasional, telah diupayakan oleh Non-Governmental Organizations (NGOs) terutama forum For Corporate Governance in Indoensia ( FCGI) dan Indonesian Society of Independent Commissioners (ISICOM) yang aktif mengadakan berbagai seminar dan publikasi untuk mensosialisasikan GCG kepada dunia bisnis Indonesia. Hasil kolaborasi dua NGO dengan NCCG tela h menghasilkan dua panduan komisaris independent dan panduan komite audit yang diluncurkan di Jakarta tahun 2004. ${ }^{2}$

Pedoman untuk melaksanan GCG telah ada semenjak tahun 2001 dan telah direvisi tahun 2006, pedoman ini tidak mempunyai kekuatan hukum yang mengikat, namun merupakan rujukan bagi dunia usaha dalam menerapkan GCG. Pedoman merupakan rujukan mengenai langkah langkah yang perlu ditempuh untuk menciptakan situasi check and balance , menegakkan transparansi dan akuntablitas serta merealisasikan tnggung jawab sosial untuk kelangsungan hidup perusahaan. ${ }^{3}$

Dalam dunia usaha, setiap pelaku usaha dalam melakukan kegiatannya perlu adanya suatau wadah, dimana kegiatan usaha tersebut ditata oleh para pelaksananya. Wadah tersebut dapat diciptakan dalam berbagai macam bentuk sesuai dengan kebutuhan. Perseroan terbatas adalah salah satu wadah untuk melakukan kegiatan usaha, yang membatasi tanggung jawab pemilik modal, sebesar jumlah saham yang dimiliki.

\footnotetext{
${ }^{1}$ Antonius Alijoyo www.@yahoo.com diakses 17 Februari 2009

2 I. Nyoman Tjager :diskusi panel Pusat Pengajian Hukum Tentang Pasar Modal : News letter No.23/1995, hkm. 23

${ }^{3}$ Mas Ahmad Daniri : Pedoman Umum Good Corporate Governance di Indonesia ,2006
} 
Pada perusahaan semacam ini, pemisahan antara pemilik modal dengan pimpinan perusahaan dapat terlihat dengan jelas. Fungsi masingmasing pihak tidak dapat dipadukan, pemilik adalah pihak yang menyediakan modal dan pengelola pihak yang memanfaatkan modal untuk menjalankan kegiatan ekonomi perusahaan.

Peran masing- masing dapat bergeser sesuai dengan besar, sifat kegiatan dan peraturan yang berlaku. Demikian pula tingkah laku masing-masing dapat saling tidak mendukung kepentingan perusahaan. Namun kepentingan pemilik tidak sama dengan kepentingan perseroan. Ada suatu konsep yang mengatakan bahwa tugas dewan komisaris adalah memperhatikan kepentingan pemegang saham sebagai pemilik perseroan. ${ }^{4}$ Perkembangan selanjutanya menurut pasal 108/2 ayat 1 UUPT No. 40 tahun 2007, dewan komisaris melakukan pengawasan dan pemberian nasehat untuk kepentingan perseroan. Hal ini senada dengan ketentuan Pasal 92/1, UUPT yang mengatakan direksi menjalankan perseroan untuk kepentingan perseroan dan sesuai dengan maksud dan tujuan perseroan.

Dewan komisaris adalah terjemahan dari raad van commissarisen sebagaimana diatur dalam KUHD, yang sebetulnya tidak banyak berbeda dengan undang-undang di Negeri Belanda. Namun perubahan undang undang di negeri Belanda menyebabkan fungsi dari raad van commissarisen juga berubah, tetapi dengan berlakunya UU No 40 Tahun 2007' maka fungsi dewan komisaris sudah dapat disesuaikan dengan yang di negeri Belanda, yaitu dewan komisaris bekerja untuk kepentingan perseroan sesuai dengan maksud dan tujuan perseroan (pasal 108/2 UUPT).

Berdasarkan uraian di atas, masalah yang menarik untuk dikaji adalah bagaimana peran komisaris independen dalam menjaga keseimbangan kepentingan antara pemegang saham mayoritas dan minoritas.

\section{Komisaris dan Good Corporate Governance}

Dewasa ini raad van commissarisen/dewan komisaris merupakan lembaga pengawasan semata-mata untuk kepentingan perseroan, dia tidak lagi bertindak atas nama pemegang saham, tetapi harus mempertahankan kepentingan perseroan terhadap siapa saja, termasuk pemegang saham. Pandangan ini lahir akibat perkembangan pada akhir tahun enampuluhan

${ }^{4}$ Moenaf H. Regar: Dewan Komisaris Peranannya sebagai Organ Perseroan: Bumi Aksara, 2000, hlm. 45 
dari dunia usaha, yang meningkatkan perhatian terhadap kepentingan masyarakat. Fungsi perseroan bukan lagi hanya melihat kepentingan pemegang saham dan pimpinan, tetapi berpaling kepada tuntutan untuk kepentingan masyarakat yang dianggap sebagai pihak yang harus diutamakan. Pemegang saham meskipun sebagai pemilik tidak perlu diperlakukan khusus. Sebagai pemilik, haknya dapat dipindahtangankan pada siapa saja. Perseroan sebagai badan hukum tidak berbeda dengan perseorangan dan dianggap sebagai anggota masyarakat, oleh karena itu keberadaannya bukan untuk kepentingan golongan tertentu. Di lain pihak, perseroan dianggap sebagai sesuatu yang bermanfaat bagi masyarakat, oleh karena itu harus dijaga melalui perangkat yang tidak berpihak dan bukan mewakili pemegang saham. ${ }^{5}$

Badan hukum sebagai subjek hukum mandiri yang dipersamakan di hadapan hukum dengan individu pribadi orang perorangan, meskipun dapat menjadi penyandang hak dan kewajiban, terlepas dari orang yang mendirikan atau menjadi anggota dari badan hukum tersebut, tidaklah seratus persen sama dengan individu pribadi atau perorangan. Badan hukum hanya dipersamakan dengan pribadi orang perorangan, dalam lapangan hukum benda dan hukum perikatan. ${ }^{6}$

Undang Undang No. 40 Tahun 2007 tentang Perseroan Terbatas (UUPT) mengharuskan adanya kelembagaan komisaris sebagai salah satu organ perseroan, bahkan perseroan yang kegiatan usahanya berkaitan dengan menghimpun dana masyarakat, perseroan yang menerbitkan surat pengakuan utang kepada masyarakat atau perseroan terbuka wajib mempunyai paling sedikit dua orang komisaris (Pasal 108/2 UUPT).

Berdasarkan undang-undang Perseroan terbatas, sistem kepengurusan terdiri dari dua jenjang yang masing masing melakukan kepengurusan dan fungsi pengawasan. Dalam hal tertentu, komisaris dapat melakukan fungsi kepengurusan perseroan. Sebagai organisasi yang teratur perseroan mempunyai organ yang terdiri Rapat umum Pemegang Saham (RUPS), Direksi dan Komisaris (Pasal 1 butir 2 UUPT). Keteraturan organisasi dapat diketahui melalui undang-undang perseroan, anggaran dasar perseroan, anggaran rumah tangga perseroan, dan keputusan rapat umum pemegang saham.

\footnotetext{
${ }^{5}$ Moenaf.H Regar, Ibid., hlm. 21

${ }^{6}$ Gunawan Widjaya, Risiko Hukum Sebagai Direksi, Komisaris \& Pemilik PT, 2008, hlm. 14
} 
Kedudukan komisaris bukanlah kedudukan yang empuk tanpa risiko, karena UUPT menetapkan persyaratan yang cukup ketat bagi seseorang yang ingin menduduki jabatan sebagai komisaris. Harus memiliki fiduciary duties terhadap perseroan mengenai kepemilikan sahamnya di perseroan. Dengan menyampaikan laporan kepemilikan saham tersebut, dapat dicegah terjadinya benturan kepentingan yang merugikan perseroan (Pedoman tentang Komisaris Independen: 2008)

Dalam rangka mengawasi dan menegakkan pelaksanaan fiduciary duties oleh Direksi atau Komisaris, UUPT menetapkan bahwa pemegang saham yang mewakili paling sedikit 1/10 bagian jumlah saham dengan hak suara yang sah dapat mengajukan gugatan terhadap direksi atau komisaris yang karena kesalahannya atau kelalaiannya menimbulkan kerugian terhadap perseroan (Pasal 97/6 dan pasal 114/6 UUPT).

Dewan komisaris adalah organ perseroan yang bertugas melakukan pengawasan secara umum dan/atau khusus sesuai dengan anggaran dasar serta memberikan nasihat kepada direksi (Pasal 1-butir 6 dan Pasal 108 ayat 1 dan 2 UUPT) sehubungan tanggung jawab dewan komisaris dapat dikatakan bahwa hubungan kepercayaan dan fiduciary duties anggota direksi secara mutatis mutandis berlaku bagi anggota dewan komisaris.

Sebagai akibat komisaris merupakan majelis, maka seorang komisaris tidak dapat bertindak sendiri-sendiri. Persyaratan untuk menjadi anggota komisaris cukup berat, Pasal 110 UUPT menguraikan syarat untuk menjadi anggota dewan komisaris harus cakap melakukan tindakan hukum, selain itu ada syarat lain, yaitu dalam 5 (lima) tahun terakhir sebelum pengangkatannya tidak pernah dinyatakan pailit atau menjadi direksi atau anggota komisaris yang dinyatakan bersalah menyebabkan suatu perseroan dinyatakan pailit atau dihukum melakukan tindak pidana yang merugikan keuangan negara dan atau berkaitan dengan sektor keuangan.

Good Corporate Governance (GCG) terjemahan bebasnya adalah tata kelola perusahaan dengan baik. Sejak Indonesia terperosok dalam krisis ekonomi, maka Good Corporate Governance menjadi bagian pembenahan pengelolaan corporasi. Setiap emiten, direksi dan komisaris secara ikhlas bersedia mengubah dan menjadikan gera dari usaha mereka, telah mencerminkan prinsip tersebut. 
Menurut Bachtiar Hasan Mirasa Utara ${ }^{7}$ dunia usaha di Indonesia kelihatannya belum menyiapkan/membina/mengarahkan warganya sebagai pengusaha yang baik, bahkan tumbuhnya dunia usaha di Indnesia berjalan secara alami tanpa didukung pengetahuan yang memadai, atau lahir dari kesempatan untuk berusaha yang muncul karena situasi politik dan kekerabatan.

Dunia usaha berjalan sendiri mengikuti arah dimana mereka mendapatkan manfaat besar tanpa mau tahu pada akibat yang akan timbul. Ukuran yang selalu kita dengar adalah mumpung ada kesempatan, jadi yang dipakai pertimbangan untuk membangun suatu perusahaan adalah peluang dan bukan ukuran ekonomi. Membangun suatu perusahaan dianggap sebagai suatu seni yang menyenangkan karena risiko yang muncul pada perusahaan telah di cover dengan berbagai upaya yang ada.

Apa yang seharusnya dimilki oleh seorang entrepreneur seperti mampu memandang jauh ke depan, mampu menanggung risiko, mampu berinovasi dan berafiliasi dengan mitra usaha yang lain hampir tidak ada. Para pengusaha lebih menyukai pola pikir jangka pendek daripada jangka panjang, dan hal ini sesuai dengan peluang yang mereka terima pada waktu itu.

Beberapa hal yang perlu digarisbawahi, untuk dapat menilai dunia usaha di Indonesia saat ini adalah: (a) ketertutupan diri pengusaha baik pemilik maupun manajer (b) tidak dipergunakan kaidah- kaidah usaha dalam bekerja karena lebih menyukai lobi (c) kurang kesiapan sebagai entrepreneur yang mampu membawanya ke dunia usaha murni. Hal ini membawa pengusaha jauh dari Good Corporate Governance (GCG),

Secara formal Good Corporate Governance (GCG) hanya ditujukan bagi perusahaan yang statusnya merupakan perusahaan public, khususnya emiten yang telah menyerap dana dari masyarakat dan memiliki saham publik yang sifatnya minoritas dan independen.

Good Corporate Governance (GCG) diperlukan untuk mendorong pasar yang transparan, effisien, dan konsisten dengan peraturan perundangundangan. Oleh karena itu, penerapan GCG perlu didukung oleh tiga pilar yang saling berhubungan, yaitu negara dan perangkatnya sebagai regulator, dunia usaha sebagai pelaku pasar, dan masyarakat sebagai pengguna produk dan jasa dunia usaha.

${ }^{7}$ wikimu.com/news/displey.News.aspx.id. diakses tanggal 5 Juli 2009 
Pada era bisnis pasca perang dingin banyak pelaku bisnis dengan berbagai macam jenis korporasi mulai menjalankan tatakelola perusahaan dengan baik secara terbuka, sistematis dan bertanggung jawab. Hal ini terdorong kebutuhan pasar yang menuntut perusahaan publik menjalankan sistem manajemennya secara baik, transparan, dan auditable, menyusul maraknya berbagai skandal sistem pelaporan keuangan perusahaan- perusahaan global beberapa tahun yang lalu. ${ }^{8}$ Menurut konsep GCG perusahaan akan memperoleh nilai perusahaan yang maksimal apabila fungsi dan tugas masing-masing pelaku organisasi bisnis yang modern dapat dipisahkan dengan bentuk: (1) Board of Directors (BOD), dengan syarat mereka bekerja full time dengan tidak boleh merangkap pekerjaan. Mereka mengelola perusahaan melalui berbagai keputusan managerial perusahaan. (2) Board of Commisionners (BOC), meliputi komisaris biasa dan komisaris independen serta berbagai komite yang dibentuknya. Fungsi utama BOC adalah mengawasi arah kepengurusan dan jalannya perusahaan menurut prinsip GCG.

Agar fungsi dan tugas Dewan Komisaris (Dekom) berjalan dengan baik, perlu dipastikan bahwa setiap kebijakan dan keputusan Dekom yang dikeluarkan tidak memihak kepentingan BOD sebagai agent, atau bias dengan kepentingan pemilik.

Dalam hal ini komisaris independen dapat berperan untuk mewakili pemegang saham minoritas.

Good Corporate Governance (GCG) yaitu transparansi, akuntabilitas, responbiitas, independensi, serta kewajaran dan kesetaraan (fairness) diperlukan untuk mencapai kesinambungan usaha (sustainability) dengan memperhatikan pemangku kepentingan (stakeholders). ${ }^{9}$

\section{Transparansi}

Tujuan adanya transparansi adalah agar perusahaan menyediakan informasi yang material dan relevan dengan cara yang mudah untuk diakses dan dipahami oleh pemangku kepentingan. Perusahaan harus mengambil inisiatif untuk mengungkapkan tidak hanya masalah yang disyaratkan oleh peraturan per undang-undangan, tetapi juga hal penting untuk pengambilan keputusan oleh pemegang saham, kreditur dan pemangku kepentingan lainnya. Hal ini perlu dibangun berbagai sistem

\footnotetext{
${ }^{8}$ Indonesian Market Link Network: 2000

${ }^{9}$ Pedoman Umum Pelaksanaan GcG Indoensia 2006
} 
prosedur yang baku untuk ditaati dalam mengambil keputusan penting yang berkaitan dengan asas transparansi ini, mencakup antara lain penunjukan komisaris, direksi, remunerasi komisaris dan direksi, kinerja komisaris dan direksi, hubungan dengan pihak eksternal, transaksi dengan pihak ketiga, dan penunjukan auditor.

Pada tahap awal, Board Of Directors dan Board of Commisaris perlu memastikan bahwa eksternal auditor, internal auditor dan komite audit mempunyai akses terhadap informasi yang dimiliki perusahaan, dengan syarat kerahasiaan informasi perusahaan tetap terjaga. Board Of Directors dan Board of Commisaris perlu memberikan laporan corporate governance kepada pihak pemerintah atau badan pengawas internal ( Bank Indonesia, Bapepam, kantor Meneg BUMN). Perusahaan juga perlu menyampaikan kepada publik sejauh mana tingkat kepatuhan yang telah mereka jalankan terhadap ketentuan perundang-undangan yang berlaku (prosedur akutansi, perpajakan dll).

\section{Akuntabilitas}

Perusahaan harus dapat mempertanggungjawabkan kinerjanya secara transparan. Untuk perusahaan harus dikelola dengan benar, terukur dan sesuai dengan kepentingan perusahaan dengan tetap memperhitungkan kepentingan pemegang saham dan pemangku kepentingan yang lain. Akuntabilitas merupakan prasyarat yang diperlukan untuk mencapai kinerja yang berkesinambungan.

\section{Independensi}

Prinsip ini dipergunakan untuk melancarkan pelaksanaan GCG, perusahaan harus dikelola secara independen sehingga masing-masing organ perusahaan tidak saling mendominasi dan tidak dapat diintervensi oleh pihak lain.

\section{Fairness ( kewajaran dan kesetaraan)}

Perusahaan dalam melakukan kegiatan, harus senantiasa memperhatikan kepentingan pemegang saham dan pemangku kepentingan lainnya berdasarkan asas kewajaran dan kesetaraan. ${ }^{10}$

Perlakuan setara terhadap pemegang saham, mencerminkan sifat adil, pemegang saham yang memiliki saham dengan klasifikasi yang sama,

10 Ibid 
harus diperlakukan setara terhadap perseroan. Equitable treatment of shareholders atau perlakuan yang sama terhadap pemegang saham. khususnya terhadap pemegang saham minoritas dan pemegang saham dari luar negeri. ${ }^{11}$

Hal ini sehubungan dengan kewajiban emiten dalam menjalankan prinsip keterbukaan (full disclosure) terhadap informasi yang bersifat material dan larangan terhadap praktik perdagangan orang dalam yang mempergunakan inside information, semua pemegng saham yang berasal dari semua jenis saham wajib diperlakukan sama, serta setiap dewan komisaris, direksi dan pegawai perseroan wajib menginformasikan bila terdapat kepentingan dalam transaksi perseroan. ${ }^{12}$ Prinsip akuntabilitas ditujukan bagi pemegang saham yang memiliki kepentingan pengendalian dalam perseroan, harus menyadari tanggung jawabnya pada saat ia menggunakan pengaruhnya atas manajemen perusahaan, baik dengan menggunakan hak suara mereka atau dengan menggunakan cara lain. Atau dengan kata lain perusahaan harus dikelola dengan iktikad baik dan bertanggung jawab untuk kepentingan perseroan. Campur tangan dalam manajemen perseroan yang melanggar hukum, harus ditanggulangi dengan cara meningkatkan keterbukaan perseroan dan akuntbilitas manajemen perseroan, serta pada akhirnya harus diselesaikan sesuai prosedur hukum yang berlaku. Pemegang saham minoritas harus mempunyai tanggung jawab serupa, yakni mereka tidak boleh menyalahgunakan hak mereka menurut peraturan perundangan yang berlaku. $^{13}$

Sehubungan dengan hal tersebut, dalam rangka pelaksanaan prinsip Good Corporate Governance (GCG), maka dunia usaha sekarang ini, memerlukan komisaris independen yang duduk dalam jajaran pengurus perseroan. Perkembangan ini patut mendapat pujian, karena memperlihatkan adanya kesadaran untuk menata ulang keberadaan dan kegiatan usahanya secara baik. Diharapkan kehadiran komisaris independent tidak hanya sekedar simbol, atau hiasan, bahkan ada yang menyebutkan sebagai schock terapy bagi orang yang bermaksud tidak baik terhadap perseroan. Tidak berfungsinya komisaris independen diperkirakan membuka peluang perusahaan melakukan kecurangan. Padahal kehadiran komisaris

\footnotetext{
${ }^{11}$ Indonesian Market Link ...Op., Cit

12 Pedoman Umum ... Op., Cit

13 Sinar Harapan , 10 Oktober-2004
} 
independen penting bagi terciptanya penyelenggaraan perusahaan dengan baik. ${ }^{13}$

Sebetulnya tugas seorang komisaris independen sangat berat dan mempunyai tanggung jawab sangat besar, bahkan diibaratkan sebagai malaikat untuk membawa perbaikan bagi perusahaan. Sebagai contoh, sewaktu jaman Orde Baru, banyak pensiunan Jenderal yang diangkat sebagai komisaris, meskipun mereka jarang ke kekantor, bahkan mereka tidak tahu seluk beluk dan permasalahan perseroan, dimana dia didudukkan sebagai komisaris. Di dalam suatu perseroan, diwajibkan mempunyai sekurang-kurangnya satu orang komisaris yang independen dan satu orang komisaris utusan (Pasal 120/1 UUPT ).

Pengertian dari komisaris independen adalah anggota dewan komisaris yang tidak terafiliasi dengan direksi, anggota dewan komisaris lainnya dan pemegang saham pengendali, serta bebas dari hubungan bisnis atau hubungan lainnya yang dapat mempengaruhi kemampuannya untuk bertindak independen atau bertindak semata-mata untuk kepentingan perseroan. ${ }^{14}$

Status independen terfokus kepada tanggung jawab untuk melindungi pemegang saham, khususnya pemegang saham independen dari praktik curang atau melakukan tindak kejahatan pasar modal.

Menurut Emmy Yuhassarie ${ }^{15}$ pemahaman dan pengaturan komisaris independen di Indoensia merupakan hal yang relatif baru dan masih dalam proses pencarian atau memposisikan secara tepat, oleh karena itu kita tidak perlu secara buru-buru untuk memilih upaya memahami secara benar. Kita perlu melakukan studi dan pengkajian secara serius dan mendalam, sebelum membuat peraturan agar komisaris indenden menjadi fungsional. Dikhawatirkan bila tidak hati hati kita akan terjebak pada hal hal yang sifatnya superficial dan pada akhirnya perusahaan hanya puas dengan hadirnya atribut tersebut, dan akibat selanjutnya komisaris independen berakhir hanya sebagai assesoris.

Peluang melakukan kecurangan dimungkinkan karena rendahnya tanggung jawab sosial. Menurut Subarto Zaini, perusahaan publik di Indonesia harus lebih banyak belajar dari perusahaan lain di luar negeri terutama perusahaan yang memilki reputasi bagus dalam penerapan GCG. ${ }^{16}$

\footnotetext{
${ }^{14}$ PedomanUmum ... Op., Cit

${ }^{15}$ Majalah News Letter :2002

${ }^{16}$ Sinar Harapan.co.id: 10 Oktober 2004, diakses 15-1-2009
} 
Dalam Undang-undang Perseroan Terbatas (UUPT) Nomor 40 tahun 2007, telah mengatur dan mewajibkan bahwa dalam Anggaran Dasar Perseroan untuk menempatkan minimal satu orang komisaris independen dan satu orang komisaris utusan. Diharapkan dengan diangkatnya komisaris independen dapat bertindak sebagai wasit. Selain itu komisaris independen dapat menghindari benturan kepentingan antara pemegang saham mayoritas dan minoritas. Dalam suatu perseroan komisaris diharapkan menjadi penyeimbang terhadap keputusan yang dibuat oleh pemegang saham mayortas, jadi seperti mewakili pemegang saham minoritas. Ini dimaksudkan agar kepentingan pemegang saham minoritas tidak terabaikan.

Keberadaan komisaris independen memang menghembuskan nafas segar bagi pelaku usaha pasar modal, diharapkan mereka akan membawakan suara para pemegang saham minoritas dalam sebuah perusahaan yang Go Public. Oleh karena itu siapa saja yang menjadi komisaris independen haruslah orang yang mempunyai integritas, kredibel dan profesional. Selain itu jangan sampai mereka mau disogok demi kepentingan pemegang saham mayoritas. ${ }^{17}$ Dalam persepektif hukum acuan yang menjadi landasan komisaris independen. Pertama, acuan tentang kedudukan komisaris dalam suatu perseroan terbatas diatur dalam Pasal 108 s/d 121 UUPT. Kedua, ketentuan Pasal 80 UU No. 8 Tahun 1995 tentang Pasar Modal, yaitu tanggung jawab atas informasi yang tidak benar dan menyesatkan, dimana komisaris termasuk pihak yang diancam oleh pasal tersebut bila ikut menandatangani setiap dokumen yang berhubungan dengan penyampaian informasi kepada publik, di dalam rangka pernyataan pendaftaran. Ketiga, adanya pedoman yang dikeluarkan Komite Nasional Good Corporate Governance (2006), sehubungan dengan kehadiran komisaris independen, menurut pedoman Umum GCG Indonesia bagian IV-c, pada prinsipnya menyatakan "dewan komisaris sebagai organ perusahaan bertugas dan bertanggung jawab secara kolektif untuk melakukan pengawasan dan memberikan nasehat kepada direksi serta memastikan bahwa perusahaan telah melaksanakan GCG. Dewan komisaris tidak boleh ikut serta dalam mengambil keputusan operasional. Kedudukan dewan komisaris termasuk komisaris utama adalah setara. Kedudukan komisaris sebagai primus inter proses adalah mengkoordinasikan kegiatan dewan komisaris."

\footnotetext{
${ }^{17}$ Sinar Harapan.co.id: 24 Oktober 2004, diakses 15-1-2009
} 


\section{Posisi Komisaris Independen Dihadapkan dengan Posisi Board Of Director (BOD)}

Secara teori dan praktik fungsi organ perseroan board of director/ dewan direktur (BOD) melakukan perbuatan kepengurusan, sedang fungsi dewan komisaris (Dekom) melakukan fungsi kepengawasan, mereka harus melakukan kemampuan terbaiknya untuk kepentingan perseroan. Emmy Yuhassarie (2000) mempertanyakan seberapa besar pengaruh komisaris independen pada dewan komisaris dalam komposisi 30\% lawan $70 \%$. Meskipun ada yang berpendapat bahwa sepanjang komisaris independen dapat melakukan dissenting, maka tidak ada masalah. Namun tujuan menghadirkan komisaris independen bukan sekedar dissenting, tetapi mampu menyeimbangkan pengambilan keputusan dewan komisaris. Oleh sebab itu, harus ada tolak ukur penilaian kinerja board of director/dewan direktur. Atau performa perusahaan membaik, maka kepada siapa the credit goes?

Dalam konstruksi hukum perseroan terbatas, maka kinerja perseroan adalah performa board of director/dewan direktur. Hal ini sebagai konsekuensi bahwa BOD menjalankan fungsi kepengurusan. Oleh sebab itu, dapat dipertimbangkan untuk membuat tolok ukur atau kondisi untuk dapat menilai performa dari Dekom.

Board of Director adalah pilihan pemegang saham yang mewakili kepentingan mereka. Oleh karena itu, dewan ini tidak independen, tetapi dalam setiap masalah berpihak kepada pemegang saham.

Konsep ini berdasarkan pemikiran bahwa perseroan didirikan oleh pemilik sebagai pemegang saham terutama untuk kepentingannya. Perbedaan kepentingan juga dapat terjadi di antara pemegang saham. Tidak jarang Perusahaan yang terdaftar di Bursa efek, terdapat berbagai kelompok pemegang saham yang mempunyai kepentingan yang berlainan, terutama bagi perusahaan yang mempunyai pemegang saham mayoritas dan minoritas, kepentingan tidak selalu searah. Keadaan ini termasuk di Indonesia, semua perusahaan yang diperdagangkan di Bursa efek selalu dikuasai pemegang saham mayoritas.

Kedudukan pemegang saham minoritas yang jumlahnya besar dan tersebar tidak dapat dipersatukan dan sering tidak terwakili dalam pengambilan keputusan, menyebabkan kewenangan dan kedudukannya tidak terwakili dalam pengambilan keputusan. 


\section{Bentuk dan Kualitas Pengawasan}

Efektifitas dari komisaris independen sangat tergantung bagaimana desain dan kualitas pengawasan harus diterapkan secara terus menerus, perilaku dan tanggung jawab hukum terhadap komisaris, kedudukan komisaris independen didesain dan dituangkan kedalam anggaran dasar perseroan. Keterkaitan antara aspek pengawasan dan tanggung jawab yuridis di dalam setiap langkah usaha yang dilakukan manajemen akan sangat mempengaruhi kemandirian dan keputusan yang dibuat oleh komisaris independen.

Kemampuan dan pemahaman komisaris indenpen terhadap bidang usaha emiten akan sangat mempengaruhi persetujuan dan keputusan yang dibuat, sesuai dengan tanggung jawab emiten terhadap pemegang sahamnya. Komisaris independen tidak boleh secara gegabah memberikan persetujuannya terhadap transaksi atau kegiatan emiten, yang secara material mengandung informasi yang tidak benar atau menyesatkan (Pasal 80 ayat 1 UUPasar Modal No.8/1995)

Menurut Indra Safitri, ${ }^{18}$ seluruh keputusan yang dibuat oleh komisaris independen, tidak terpisahkan dari berjalannya mekanisme internal kontrol di tubuh emiten termasuk adanya komite audit. Komite audit memproses calon auditor eksternal termasuk imbalan jasa untuk disampaikan ke dewan komisaris. Anggota Komite audit disesuaikan dengan kompleksitas perusahaan dengan tetap memperhatikan efektifitas dalam pengambilan keputusan. Bagi perusahaan yang sahamnya tercatat di Bursa efek, perusahaan negara, perusahaan daerah, perusahaan yang menghimpun dan mengelola dana dari masyarakat, perusahaan yang produk dan jasanya dipergunakan oleh masyarakat luas, serta perusahaan yang mempunyai dampak luas terhadap kelestarian lingkungan.

Komite audit diketuai oleh komisaris independen, dan anggotanya terdiri dari komisaris dan atau pelaku profesi dari luar perusahaan. Salah seorang anggota memiliki latar belakang dan kemampuan akuntansi dan keuangan. ${ }^{19}$

Ada rasa was was bila kita mencoba untuk melihat realita etika, kepatuhan hukum dan praktik bisnis di Indonesia saat ini, menyangkut peran dari komisaris independen yang ditempatkan di jajaran pengurus emiten. ${ }^{20}$

\footnotetext{
${ }^{18}$ Indonesia Market Link Network, 2002, diakses tanggal 12 Januari 2009

${ }^{19}$ Indonesia Market Link Network, 2002, diakses tanggal 5 Juli 2009

${ }^{20}$ Pedoman Umum... Op., Cit
} 
Soal sejauhmana kesungguhan dan kesanggupan komisaris independen untuk dapat benar benar independen dan mampu menolak pengaruh, intervensi atau tekanan dari manajemen atau pemegang saham mayoritas yang memiliki kepentingan atas transaksi atau keputusan tertentu. sebab rata rata struktur kepemilikan saham emiten, masih terkait kontrol mayoritas pemegang saham di dalam menjalankan perusahaannya, maka ketangguhan komisaris independen untuk tidak menyerah dan terhindar dari unsur benturan kepentingan merupakan ujian berat. Jaman Orde Baru banyak anak, saudara, cucu bahkan saudara jauh pejabat, petinggi atau mantan jenderal yang duduk sebagai komisaris hanya sekedar bertujuan untu membuka akses hubungan kousi antara pengusaha dan pemerintah. Sehingga pada waktu itu ada yang namanya komisaris aktif dan tidak aktif.

(1) Insentifitas pengawasan yang terus menerus mensyaratkan aktifitas dan perhatian setiap individu yang terpilih sebagai komisaris independen, di dalam mengawasi kegiatan perseroan tidak dapat terpecah dengan adanya pekerjaan atau kesibukan lainnya. Untuk itu emiten yang memilki komisaris independen hendaknya mereka yang berkemampuan, berpengetahuan serta mempunyai waktu dan intergritas yang tinggi di dalam menjalankan tugas dan tanggung jawab yang ada.

(2) Kualitas pengawasan juga ditentukan oleh bagaiman desain pengambilan keputusan bersama jajaran komisaris lainnya dan terpenuhi persyaratan yang ditentukan oleh bursa efek.

PT Bursa Efek Jakarta (BEJ) di dalam peraturan pencatatan Efek No.1A: tentang Ketentuan Umum Pencatatan Efek yang bersifat Ekuitas di Bursa, dalam angka 1-a menyebutkan tentang ratio komisaris independen yaitu: komisaris independen yang jumlahnya secara proporsional sebanding dengan jumlah saham yang dimiliki oleh yang bukan pemegang saham pengendali dengan ketentuan jumlah komisaris independen sekurang-kurangnya 30\% dari seluruh jumlah anggota komisaris.

Menurut pendapat saya, apabila ingin mendapatkan akibat yang berarti terhadap kinerja Dewan Komisaris, maka keanggotaan komisaris independen harus lebih dari jumlah sehingga dapat outvoted dalam pengambilan keputusan. Alternatif lainnya adalah posisi yang lebih menentukan atau memberikan pengaruh diberikan untuk posisi presiden komisaris. Dewan komisaris dan dewan direksi bekerja untuk kepentingan perusahaan, baru kemudian pemegang saham, bahkan dalam likuidasi 
pemegang saham memperoleh bagian terakhir (Pasal 149/2 UUPT). Persoalannya ialah pemegang saham juga investor, dan undang undang melindungi kepentingan investor, mengapa setelah investor menjadi pemegang saham harus ditandingi dengan komisaris independen, yang bekerja untuk kepentingan perseroan.

Dalam Rapat Umum Pemegang Saham (RUPS) terdapat kekuasaan untuk menyetujui suatu rencana kerja perseroan, tetapi apabila menurut dewan direksi dan businnes judgement dari dewan direksi, rencana tersebut wajib diubah, maka dewan direksi wajib menjalankan rencana tersebut yang menurut pertimbangannya paling baik untuk dijalankan guna kepentingan perseroan. Dengan demikian manakala kepentingan perseroan tidak sejalan dengan putusan RUPS, maka dewan direksi harus lebih mengutamakan kepentingan perseroan, sebab pada akhirnya dewan direksi tidak dapat bersembunyi dibalik RUPS, atau komisaris, apabila keputusan tersebut salah. Dengan kata lain, pemberian persetujuan RUPS, maupun komisaris tidak dapat membebaskan direksi dari tanggung jawab atas kepengurusannya.

Perlu diperhatikan bahwa keputusan RUPS dan komisaris bukanlah tindakan kepengurusan, karena instruksi tersebut tidak wajib dilaksanakan oleh direksi. Dengan demikian direksi tetap independen, terutama untuk memutuskan apakah tindakan tersebut dilakukan atau tidak dilakukan.

\section{Hubungan Komite Audit dengan Komisaris Independen}

Menurut Pedoman Umum Good Corporate Governance Indonesia 2006, komite audit bertugas membantu dewan komisaris untuk memastikan bahwa (1) laporan keuangan disajikan secara wajar sesuai dengan prinsip akuntansi yang berlaku umum (2) struktur pengendalian internal perusahaan dilaksanakan dengan baik (3) pelaksanaan audit internal maupun eksternal dilaksanakan sesuai standar audit yang berlaku dan (4) tindak lanjut temuan hasil audit dillaksanakan oleh manajemen

\section{Tugas Dan Tanggung Jawab Komite Audit}

Tugas dan pembentukan Komite audit adlah untuk memberdayakan fungsi komisaris dalam melakukan pengawasan. Komite Audit yang efektif akan membantu terciptanya keterbukaan, dan pelaporan keuangan yang berkualitas, ketaatan terhadap peraturan yang berlaku dan pengawasan internal yang memadai (Antonius Alijoyo, Subarto Zaini: 
2004), dengan kata lain, komite audit memungkinkan Komisaris melakukan pengawasan yang efektif dalam tiga bidang berikut: laporan keuangan; hasil usaha perusahaan; Rencana jangka panjang.

\section{Penutup}

Keberadaan komisaris independen dimaksudkan untuk menciptakan iklim yang lebih objektif, independen dan untuk menjaga fairness serta memberikan keseimbangan antara kepentingan pemegang saham mayoritas dan perlindungan terhadap kepentingan pemegang saham minoritas, bahkan kepentingan stakehorlder lainnya. Komisaris independen sangat dibutuhkan oleh perusahaan-perusahaan yang ada di Indonesia terutama bagi perusahaan publik. Dengan adanya komisaris independen semua pihak yang berkepentingan mendapatkan manfaat yang besar, terutama terbentuknya situasi yang suitable dengan prinsip Good Corporate Governance, dimana komisaris dapat memberikan pandangan dengan tingkat independensi dan akuntabilitas yang lebih tinggi.

\section{Daftar Pustaka}

Adler Heyman, Manurung , Analisis Saham Indonesia, Beberapa Saham Untuk Investasi Jangka Panjang, Economic Student Group, Jakarta, 1992

Antonius Alijoyo (www. Yahoo.com-3 Februari 2002)

Asser Van der Heijden dalam Handboek van Naamlooze Venootschap

Asriel Sitompul, Pasar Modal Penawaran Umum dan Permasalahannya, Citra Aditya Bakti, Bandung, 1996

Bambang Kesowo, Beberapa Prinsip dalam Undang-Undang Perseroan Terbatas, Newsletter No. 24/ 1996, Pusat Pengkajian Hukum, Jakarta, 1996

Erik Hammerstein, Securities Regulation in The Netherlands, Makalah pada seminar Studi Perbandingan tentang Hukum Pasar Modal, 1995

Fred B.G. Tumbuan, Fiduciary Duties Direksi Perseroan Terbatas Menurut Undang-Undang No 1/ 1995, Newsletter No. 23/ 12/ 1995, Pusat Pengkajian Hukum, Jakarta, 1995

Gunawan Widjaya, Risiko Hukum Sebagai Direksi, Komisaris \& Pemilik PT, 2008

Henry Black Campbell, Black's Law Dictionary, Abriged Fourth Edition, 1983

Indra Safitri, Indoensian Market Links Net Work 2002 
I Nyoman Tjager, Diskusi Panel Pusat Pengkajian Hukum tentang Pasar Modal, Newsletter No. 23/ VI/ 1995

I Gusti Rai Widjaya, Penanaman Modal, Pedoman Prosedur Mendirikan dan Menjalankan Perusahaan dalam rangka PMA dan PMDN, Pradnya Paramitha, Jakarta, 2003

John Downer, Jordan Elliot Goodman, Keuangan dan Investasi, Elex Media Komputindo, Jakarta, 1994ku

Kansil, C.S.T. Pokok-Pokok Pengetahuan Hukum Dagang Indonesia, Aksara Baru, Jakarta, 1980

Kartini Mulyadi, Aspek-Aspek Hukum Emisi Obligasi Pemerintah Pusat, Pemerintah Daerah, BUMN dan Perusahaan Swasta, Aksara Baru, Jakarta, 1990.

Moenaf Regar, Dewan Komisaris Peranannya Sebagai Organ Perseroan, Jakarta, Bumi Aksara, 2000.

Munir Fuady, Pasar Modal Moderen (Suatu Tinjauan Hukum), Citra Aditya Bakti, Bandung, 1996

, Doktrin-Doktrin Modern Dalam Corporate Law: Eksistensinya dalam Hukum Indonesia, Citra Aditya Bakti, Bandung, 2002

Pedoman umum Good Corporate Governance ,2006

Ruchiyat Kosasih, Diskusi Panel Pusat Pengkajian Hukum tentang Pasar Modal, Newsletter No. 23/ VI/ 1995

Rudhy Prasetia, Kedudukan Mandiri Perseroan Terbatas, Citra Aditya Bakti, Jakarta, 1995

- Upaya Mencegah Penyalahgunaan Badan Hukum, Makalah dalam Temu Karya Hukum Perusahaan dan Arbitrase, Jakarta, 1991

Setiawan, Aspek Hukum Pemilikan Saham: Penyalahgunaan Badan Hukum dan Penyitaan Saham, dalam Majalah Varia Peradilan No. 52 Tahun $\mathrm{V}$, Januari 1990

Soekanto Winahyo," Sebuah Pengantar tentang Pertanggungjawaban Hukum Direksi BUMN: Kasus Tempo", Newsletter No. 18/ IX/ 1994, Pusat Pengkajian Hukum, Jakarta, 1994

Zen Purba, The Current Status of Company Law in Indonesia, dalam Hukum dan Pembangunan No. 6/ 1994, Fakultas Hukum Universitas Indonesia, Jakarta, 1994 